\title{
Japan and South Asia: Toward a Strengthened Economic Cooperation
}

\author{
Monir Hossain Moni \\ Assistant Professor, Department of Political Science and Japan Study Center, \\ Faculty of Social Sciences, University of Dhaka, Dhaka, Bangladesh
}

\begin{abstract}
While in the whole scenario of contemporary Asia-Pacific's economic prosperity, Japan's catalytic role is continuing to evolve, ironically in this region's sprawling vibrant landscape, the only backward sub-region that has not yet kept pace with this changing trend is South Asia. Despite the magnitude of Japanese development aid to all South Asian nations, the region's share in Japan's global trade and investment is too small to merit much attention. Moreover, in Tokyo's strategic-diplomatic agenda, South Asia has in fact figured little for a long time, because it has been relevant neither to Japan's security necessities nor the needs for a global economic governance framework. Nonetheless, Japan has very recently shown a heightened interest in expanding its cooperation with South Asia (particularly India). Under this backdrop, this article strives to explore the reasons why South Asia has today risen strategically in significance to the breadth of Japanese foreign policy initiatives. The study argues that for mutual values and benefits, the economic and geo-strategic partnership between Japan and South Asia needs to be nourished more effectively and constructively. This comprehensive policy-relevant scholarly piece concludes with a reasonable expectation that Tokyo's policy towards South Asia will embrace a comprehensive review process with an action-oriented roadmap in a strongly competitive and dynamically changing Asia.
\end{abstract}

KEYWORDS: Japan, South Asia, India, economic cooperation, Asian integration, geo-strategic relationship

John Hay, Secretary of State of US President Theodore Roosevelt, declared in 1903 that "The Mediterranean is the ocean of the past, the Atlantic is the ocean of the present, and the Pacific is the ocean of the future." "The Pacific future is absolutely imminent. In today's increasingly interconnected world, the term "Asia-Pacific" has become a part of our daily politico-economic parlance. The nations of the Asia-Pacific region have today taken on accelerated global significance, and the speed of the region's progress during recent decades finds no comparison in human history (Borthwick, 1998). The reasons for this "miracle" can be found in the rapid growth of the region's export-oriented industries and trade made possible by technological advancements, information revolution as well as intra-regional and extra-regional flows of capital (Terry, 2002; Thompson, 1998). It is indeed estimated that over the next decade, all of Asia might contribute 
between one-half to two-thirds of world economic growth. Despite contemporary economic malaise, the prosperity made by South Korea, Taiwan and several Southeast Asian nations is really impressive. With the implementation of reform plans, particularly since its entry to the World Trade Organization (WTO) in 2001, China is also on the pathway to faster economic growth.

More strikingly, within this most sprawling region, Japan has not only emerged as an economic superpower, but also has become an enviable "role model" for many developing economies. In the entire spectrum of today's Asia-Pacific's economic development, Japan's growing catalytic "soft power" role has been quite recognizable. Furthermore, from the very outset of its accession to the United Nations (UN) in 1956, Japan in a manner commensurate with its world status as the biggest donor country has strenuously and consistently been shouldering a greater financial commitment to the entire system of the universal body (Fukushima, 1999; Kawabe, 1994). Being a nation belonging to Asia, Japan also remains a key regional geopolitical position (Blechinger \& Legewie, 2000; Kobayashi, 1991), and it has come forward to play a decisive role in a wider array of domains within the region in the new millennium (Tho, Yutaka, \& Kwan, 2001), even defying its economic recession trend.

Notwithstanding, very regrettably in this region's dynamic landscape, the only underdeveloped subregion that has not yet kept pace with this invigorating look is South Asia, consisting of the following seven member countries of the South Asian Association for Regional Cooperation (SAARC): India, Pakistan, Bangladesh, Sri Lanka, Nepal, Bhutan and the Maldives. It is evident that in the scope of Japanese foreign policy towards Asia, its relationship with China, two Koreas and some member states of the Association of Southeast Asian nations (ASEAN) has been one of the most prioritized agenda. In contrast, South Asia was rarely among Tokyo's diplomatic priorities. During the Cold War, ideological inhibitions and the insularity of the South Asian nations had pushed the region to the margins of
Japanese diplomacy (Hirose, 1996). Although the Japanese business circles have not demonstrated their considerable interest in the region for a long time, apart from a very few that have recently shown eagerness regarding India, interaction between the two sides has entered a new phase since the beginning of the 1990s.

Admitting that Japan, with the enormousness of its official development assistance (ODA) has today become one of the most important factors affecting the national interests of all South Asian countries, one should not overlook the glaring asymmetry that marks their economic relations. The potential of Japan-South Asia economic cooperation in the key areas of trade and foreign direct investment (FDI) is yet to be fully tapped. The South Asian economies have already tried their best to attract Japanese investors by offering a package of incentives and facilities. But the reality is that they have not yet shown synergy through moving forward with their investment resources in this region. Likewise, there has always been a huge trade deficit on South Asia's part in its business with Japan, whereas Japan holds a notable position in South Asian trade. However, while the strategic significance of South Asia in a fast moving Asia is now recognized, it is unfortunate that the tarnishing image of most South Asian nations abroad intrinsically caused by poor governance and political volatility exists more gloomily against all their positive but not properly projected potentials.

Against this crux, this rigorous policy-oriented research endeavors to analyze the cardinal constraints confronting Japan and South Asia in the realm of their economic ties, and to explore South Asia's enormous alluring prospects, which might be reconsidered when boosting Japan's partnership with this region in today's most severely challenging era of globalization. The scholarly piece surmises that beyond Japan's ever-greater ODA cooperation with South Asia, its strategic ties with the region needs to expand far more extensively. The study adopts a macro approach, and to present the nature and extent of Japan's role in South Asia, analyses encompass India to some extents, as it is the largest country in this sub-continent in terms of 
population and status as well as commercial, strategic-diplomatic and cultural connections with Japan.

\section{ECONOMIC COOPERATION AND INTEGRATION IN ASIA}

Though the terms "economic cooperation" 2 and "economic integration" 3 are often used synonymously, these two concepts are different. Indeed, "regional economic cooperation" is an evolutionary process comprising a number of stages. While economic integration represents the most advanced or ultimate phase of economic cooperation, regional economic cooperation implies collaboration among a group of nations on economic matters such that each member nation derives greater substantial benefits than what would be possible in the course of normal economic relationships without cooperation. In a broader sense, the scope of cooperation can cover a wide range of economic issues such as trade, tariffs, technology, investment, joint ventures, and fiscal and monetary policies.

In Asia, over the past decade, an increasing awareness of the interdependence among nations in the region and of the importance of regional cooperation and integration in counteracting the globalization forces has led to several decisive steps to promote regional economic cooperation goals (Ohmae, 1995). The slow progress with multilateral initiatives and the proliferation of regional blocs in other parts of the world have relatively offered extra impetus to more cooperation within the Asian region. Actually, there is a realization that open regionalism can greatly contribute to enhanced productivity and economic growth, and consequently to poverty reduction within the region. In Asia, the process of economic growth and development in the last few decades has been impressive (Kawai, 2005). While economic regionalism is still less advanced than in Europe (Katzenstein, 1997), market-driven integration through trade and investment has been a key driver of East Asia's economic growth, sustainable development, and poverty reduction. While the rise of huge regional production networks has played a pivotal role since the mid 1980 s, economic cycles are at the same time becoming more synchronized. In summary, these dynamisms have fostered interdependence and favored sustained economic growth in the Asian region. Nonetheless, economic cooperation in Asia has so far been limited principally to the bilateral or sub-regional levels as well as in the arenas of trade and investment, money and finance, and infrastructure. Most recently, however, the geographic scope of agreements has started to expand across the different sub-regions, providing initial signs of cooperation and integration in Asia as a whole (Asian Development Bank [ADB], 2005).

Another salient aspect is whether the momentum behind the institutionalization of economic cooperation and integration is "marketdriven" or "politically-driven." 4 It is evident that economic growth and development of the AsiaPacific region has predominantly been marketdriven, based on the growing inter-linkages among the business sectors in the region to support AsiaPacific Economic Cooperation (APEC). In this connection, it is intriguing to note that Japan's direct investment in China rose 19.8 percent to a record US $\$ 6.53$ billion last year, regardless of antiJapanese demonstrations in China in April 2005 (Japan's direct investment, 2006). Nevertheless, it is true that some countries or firms obviously invest for at least partly political motives, but even the most politically-driven economic partners are unlikely to actually make significant investments until an acceptable policy framework and reasonable institutional safeguards are in place.

While this research explores economic cooperation with the notions of regionalism ${ }^{5}$ and integration in Asia as a whole, such a macro approach might not be the most appropriate for this study. The Japan-South Asia economic ties may rather be perceived from a micro approach. One the one hand, as economic issues were not the too decisive political factors within/among the nations of the South Asian region, a politicallydriven economy has so far not been a success here. 
On the other, in spite of its "superiority of economic adroitness," Japan does not assess its relations with each of the developing economies of South Asia from the political motivation or the "patron-client" angle. To be more specific, the South Asian market, particularly the Indian one, and its one billion plus population, presents lucrative and diverse opportunities for Japanese exporters with the right products, services, and commitments. Although the "Japan-South Asia relationship" may basically be characterized as a "market-driven" one, their mutual cooperation may also be viewed from the geo-strategic and politico-diplomatic realms. More notably, Japan's national security interest in the South Asian region may principally lie in realizing the growing gravitas of India, because India alone is in a position to strategically assist Japan for various grounds, particularly under China's shadow in dynamically moving contours within Asia.

Moreover, one of the prominent features of the relations between Japan and South Asia, apart from its intellectual depth, is a prolonged dormant past (Ohji, 1992; Yamazaki \& Takahashi, 1993). Their historical ties go back to the beginning of the $20^{\text {th }}$ century when Asia's first Nobel laureate, Bengal's poet Rabindranath Tagore and internationally well-known Japanese cultural ideologue Tenshin Okakura profoundly affected and influenced each other's work through their friendship (Bharucha, 2006). The visit of Netaji [leader] Subhas Chandra Bose and Ras Bihari Bose to Japan to seek support and sympathy for India's freedom struggle was also a remarkable milestone in the history of India-Japan solidarity ties (Sareen, 2004). More remarkably, for Japanese people of old generation, Justice Radhabinod Pal's lone dissenting judgment during the Tokyo War Tribunal about the "validity of verdict on war crimes imposed by winners on losers" still remains vivid in memory (Nandy, 1995). Such compassion conveyed by South Asian people moved and encouraged Japanese people faced with diverse difficulties in the revival following World War II, and thus left its good impression on South Asia. Judge Pal's dissent is in fact frequently cited by Indian diplomats and political leaders in the frame of reference to Indo-Japanese alliance. In return, when India was faced with economic hardship, Japan reciprocated India's friendliness by choosing it as the first recipient country of its ODA loans in 1958.

While the relationship between Japan and South Asia in recent years has been conciliatory, they need to come to be connected by a network of shared interests in the political-diplomatic, geostrategic and socio-cultural fields, beyond the economic sphere.

\section{SOUTHASIA'S INCREASING GEO-STRATEGIC IMPORTANCE TO JAPAN}

Some analysts predict that South Asia's larger population, lower gross national income (GNI) and a high degree of disparity in per capita income (PCI), make it difficult to envision the region emerging as an economically stable one in the near future (World Bank [WB], 2005). In other words, contemporary South Asia brings to minds the images of a backward and often-neglected region, which faces socio-environmental disasters and politico-economic vulnerability. But there is no denying the fact that it has today become a geostrategically important region to the scope of Japanese diplomatic missions, and will likely grow in prominence in the future. It seems that South Asia's rising geo-strategic profile is being raised a number of notches by another global player. To be more concrete and comprehensive:

First, because of its sheer size, South Asia has greater significance in the management of global issues. The region, which covers a vast area equivalent to the whole of Europe, represents more than one-fifth of the world population. One may well argue that this weight might naturally have an incisive impact on the future of the globe, with regard to pressing issues such as human development, energy supply, food production, environmental sustainability, healthcare challenges, etc. Japan, in its quest for "responsibility sharing" in international management, would thus find it relevant to seek cooperation and policy coordination with this region. 
Second, South Asia is considered a strategically key area for Japan's energy security in the sense that Japan heavily (about 80 percent) depends on the import of oil from the Gulf region, and South Asia is located midway between this region and Japan. The so-called "sea-lanes" run through the Indian Ocean (Graham, 2005), a conveyor connecting the Pacific Ocean and the Atlantic Ocean for the traffic and transportation of oil. In particular, the small island nation of Sri Lanka is of immense geographical importance because it lies in the primary Indian Ocean shipping lanes of big oil tankers. It is in Japan's vital interest that its relations with the South Asian countries remain stable and friendly, in contrast to its standing with some East and Southeast Asian nations. Nonetheless, Japan, as the only country ever to know the horrors of nuclear devastation, is scrupulously concerned that escalation of tension between India and Pakistan could seriously damage the regional peace and stability, because both nations allegedly possess nuclear weapons of mass destruction (WMD). Japan, together with other countries, strongly reacted to a series of nuclear tests conducted by India and Pakistan in May 1998, and subsequently suspended yen loans for new projects to both countries. Even its new yen loans and fresh grants-in-aid other than those for humanitarian purposes were frozen. ${ }^{6}$ Since then, despite Japan's sincere efforts toward the normalization of relations between these two longtime rival nations, which facilitated both countries' signing of the nuclear non-proliferation treaty (NPT) and comprehensive test ban treaty (CTBT) (Japan urges nuclear states, 2005) very sadly neither of the nations has yet done so.

Third, it is clear that Japan's long-cherished aspiration to become a permanent member on the United Nations Security Council (UNSC) remains as strong as ever, but materializing this desire in the near future has become very complicated in the face of stringent objections from several corners. As there are still some qualms about Japan's permanent membership, Tokyo will have to stipulate more sedulous action plans. Since the country is determined to be successful this time, Tokyo's government will have to cultivate support bases as comprehensively as possible in future. Although Tokyo formed a lobbying group called the "G4" comprising itself, Germany, Brazil and India, the further cultivation of South Asia is strategically valuable, because Pakistan commands a great deal of clout in a number of Muslim nations, and India has justifiable influence in emerging nations because of its active role in the NonAligned Movement (NAM). ${ }^{7}$ Furthermore, Bangladesh has committed itself to supporting Japan in international affairs, reconfirming Dhaka's approval of Japan's permanent seat on the UNSC.

Fourth, the turn of the new century has heralded that Asia's time has come to be the key determinant in the global strategic calculus (Rozman, 2004). More inclusively, present-day Asia witnesses three giants namely Japan, China and India. China's economic strength and military power is on the ascendant and so is India's (Buzan, 2002). It is apparent that in East and Southeast Asia, Japan's political dominance is gradually waning owing to the growing inroads by China in the region. In this changing scenario, South Asia might anticipate that Japan has some attractive alternatives in terms of Tokyo's visionary drive toward Asian security and regionalism. It will anyhow call for a rigorous reorientation of Japan's strategies regarding South Asia with a particular salience to India. While the "strategic triangle," i.e., the Japan-China-India trilateral axis, might be conducive to their prosperity as well as the rejuvenation of Asia, the emerging power of India can no longer be ignored. It may, however, be enumerated that Japan has so far not followed any independent foreign policy concerning South Asia, and it has ever taken cues from the US policies to South Asia (Dillon, 2005). For a long time, Japan has actually perceived South Asia from the US strategic viewpoints, not from the contexts of Asian regionalism with special reference to Japan's own security and defense policies. Nevertheless, it appears that in the post9/11 scenario, Tokyo is ready to change its "myopic policy" with regard to South Asia, and further assist 
the nations of this region, keeping in mind Asian solidarity and working to understand the region's security needs.

Finally and more importantly, from the economic strategic perspective, South Asia has tremendous potential as a Japanese investment and trade market destination. Regardless of geographic location, most nations of this region have growing large markets of millions of middle-class citizens ${ }^{8}$ with huge buying capacity, high-caliber skilled and cheap labor forces, ${ }^{9}$ rich natural resources, democratic frameworks, reliable legal systems as well as economic liberalization policies. Among all, the issue of the rising economic strength of India may be of particular reference (Buzan, 2002). It may be highlighted that India's gross domestic product (GDP), calculated according to purchasing power parity (PPP), is next only to Japan and China in Asia. Recognizing the inherent strength of India's economy, the US, China, South Korea and other countries had made substantial investments in the country. For these reasons, India in particular and South Asia in general deserve the accelerated attention of Japanese investors and entrepreneurs. Japanese multinational firms could begin to tap into the prospects of the South Asian nations by setting up export bases either for home market-oriented consumption or for third-country exports.

From a comparative context particularly drawn from China, which is linked with South Asia by land and water, mountains and rivers unlike East Asia and Southeast Asia, its growing presence in South Asia is riding on its economic and strategic influence in the region. One measure of China's economic outreach is its current trade volume with all South Asian nations, which approaches US\$20 billion a year. China has rather satisfactorily invested in South Asia's smaller economies as well. Besides gaining a strategic foothold, China has benefited diplomatically from its increased connections with Bangladesh, Pakistan, Sri Lanka and Nepal. For instance, all of these nations today affirm the "one-China" policy, stating that Taiwan is an inalienable part of the People's Republic of China (PRC). This effort has transformed the region from India's "near abroad" into China's “own backyard." In short, China's rapid economic growth has its neighbors change their geo-political perception on it. The shift from a "China threat" to "China opportunity" theory unfolds the option to explore the benefits that can be drawn from the gigantic Chinese market to the inner natural and spiritual bonds with China. Whilst China's gains in reaching space in both South Asia and Southeast Asia practically stand in sharp contrast to the deepening conflicts in China-Japan relations, there is still a lack of institutionalized dialogue mechanism between South Asia and China.

With a particular focus on the SAARC, since its creation in 1985, the organization has sought to increase economic unity among its member states. Although the organization was designed to improve the socio-economic prosperity of its members, it may be asked whether it has been capable of successfully pursuing its visions. When the SAARC is compared with other regional trading bodies like the ASEAN, ASEAN Regional Forum (ARF) and the EU, it performs poorly in terms of the efforts toward boosting economic cooperation. Unlike the EU or the ASEAN, trade among and within the seven SAARC nations remains low, regardless of the fact that all are located within close proximity of one another, as well as being part of the WTO. It is also a critical question whether the SAARC will be able to play an exemplary role in ameliorating the region's prosperous tomorrow because of the dominant power of India over other member states of this organization. This imbalance of power indeed allows conflicts between India and its neighbors to undermine organizational unity. The clashes between South Asian nations end up jeopardizing the creation and effectiveness of regional trade agreements. Besides, they lead individual SAARC states to promote their economic interests through bilateral agreements, reducing the incentive to engage in multilateral relations.

While South Asia's geo-strategic relationship with other Asian economic giants needs to enter a more meaningful phase, there is a growing realization that unless India and Pakistan take bold 
Table 1.

Selected Parameters of South Asian Economies, 2004

\begin{tabular}{lrcc}
\hline Country & Population (million) & Total GNI(US\$ billion) & GNI Per Capita(US\$) \\
\hline Bangladesh & 140.49 & 61.23 & 440 \\
Bhutan & 0.89 & 0.68 & 760 \\
India & $1,079.72$ & 674.58 & 620 \\
Maldives & 0.30 & 0.75 & 2,510 \\
Nepal & 25.19 & 6.54 & 260 \\
Pakistan & 152.06 & 90.66 & 600 \\
Sri Lanka & 19.45 & 19.62 & 1,010 \\
\hline Total & $1,418.10$ & 854.06 & - \\
\hline Average & 202.59 & 122.01 & 885.70 \\
\hline
\end{tabular}

Source: World Bank

decisions to resolve the "Kashmir issue" toward ensuring a lasting peace and expediting sustainable development in South Asia through a cohesive regional integration among the countries of the region, they will not count much in the competitive world. Japan has a closer relationship with the ASEAN, because this institution plays an effective role in the regular consultations and exchanges that the Japanese government prefers over bilateral negotiations. Hence, Japan expects that the SAARC will play a similar role, by resolving territorial and other common problems within the regional cooperation framework, and speak with a collective voice. ${ }^{10}$

This notwithstanding, it is evident that India is smartly marching towards full capital account convertibility on the back of a robust economic expansion. Since joining the WTO in 1995, and with this opening to the world's markets, both as an importer and exporter, India indeed expects a larger voice towards setting the rules and norms of the global economy. However, while India has genuine economic and strategic grounds for staking a claim to a great power status, it is not such a power in the classic sense. It is because the nation is not yet able to challenge the world's superpowers. Nevertheless, in a transformed international order, its assets and resources are more important to a wider array of Japanese interests than they have been for over half a century. As they have been in the past, the enormous prospects of India in particular and South Asia in general should not simply be overlooked in the future.

\section{ECONOMIC COOPERATION}

Considering that the predominant determinant of Japanese foreign policy is "economic," and the central consideration of South Asian nations is "developmental," it is simply better to understand the economic perspective of their cooperative relationship in the aspects of ODA, trade and FDI, before other prevailing various facets of their relations are considered.

\section{ODA}

While Japan's participation in the Colombo Plan in October 1954 marked the beginning of its ODA to South Asia, Tokyo provided India with its first low-interest yen loans in 1958. Since then, Japan has gradually expanded its ODA schemes in India and other South Asian countries to help promote 
the socio-economic development of the region. In a nutshell, ODA has formed the core of Japan's postwar interaction with South Asia, and the nation has today emerged as the topmost aid donor in the region. From fiscal 1990-1991 to 2001-2002, Japan's ODA to all South Asian countries cumulated at about US $\$ 8.5$ billion. In total ODA inflows from different multilateral donor organizations, Japan's sole contribution is almost 50 percent. According to factual data, all the countries of South Asia rank high among the "top 10 " recipients in Japan's bilateral aid program, e.g., for the fiscal year 2002, India had the $5^{\text {th }}$ rank, Sri Lanka the $6^{\text {th }}$, Pakistan the $7^{\text {th }}$ rank and Bangladesh the $9^{\text {th }}$ rank according to the net disbursements of Japan's ODA (Ministry of Foreign Affairs [MOFA], 2002). In spite of this, Tokyo repeatedly announced its plans to examine resumption of multimillion yen loans to India and Pakistan, if New Delhi and Islamabad stop production of ballistic missiles and sign the nuclear NPT and CTBT (Japan wants Pakistan, 2004). Concerned with Sri Lanka, the military conflicts in the nation's northern and eastern areas and the continuation of human rights violations are a matter of concern.

As mentioned in an earlier section, South Asia has today risen geo-strategically in significance in the scope of Tokyo's diplomatic efforts, which might genuinely appeal for Japan's attention to be more responsive to the region's changing needs. South Asia prominently features in Japan's ODA, because it is considered one of the regions that seriously suffers from the merciless onslaught of natural disasters and epidemics. All nations of the region (except India), which also face floundering economies, accumulated debt and chronic poverty, fit quite well with Japan's bilateral ODA priorities, as its aid cooperation with South Asia attempts to concentrate on poverty reduction incorporating Tokyo's new economic foreign policy paradigm for "ningen no anzenhosho" [human security] (Ministry of Foreign Affairs [MOFA], 2004), and approaches the issues such as the improvement of basic living standards and stable economic growth. More to the point, Japan is committed to offer a long-term support for peace building in Sri Lanka as well as for rehabilitation efforts after damages caused by the 2004 tsunami (Japan International Cooperation Agency [JICA], 2005).

Given that the SAARC member states are least developed countries (LDCs), Japanese ODA to the region primarily consists of grant aid and technical assistance. It is noticed that the ratio of the grant element is higher in case of the smaller nations in this region, while it is minimal in the case of India. In terms of interest and maturity, Japan provides assistance on the most concessionary terms among its ODA projects to this region as well. The interest rate for loans to South Asian countries is around 1 percent, having a repayment period of 30 years with a grace period of 10 years. It should also be spelt out that Japan regards its ODA as one of the most important instruments for "kokusai koken" [international contribution] in respect to the South Asian economies, not from the "donor-dependent" point of view, as explained before. It is in this sphere that Japan and South Asia have essentially developed a fair measure of closeness and understanding (Esho, 1994).

It is an illustrative fact that a number of contributions of Japan's ODA loan aid programs to South Asia, principally in the infrastructure development sectors, have by this time been identified as "milestone successes." In the transportation and communication sector, for example, largely financed by Japan, together with the World Bank (WB), Asian Development Bank (ADB) and government of Bangladesh, the US $\$ 950$ million project of Jamuna Multipurpose Bridge (JMB), the longest in South Asia and $11^{\text {th }}$ longest in the world is one of the most thriving ones (Japan Bank for International Cooperation [JBIC], 2003), as this bridge has integrated the economy, commerce and communication of Bangladesh, particularly the country's northern region with the rest of the territory where the hub is-perhaps more than any other physical investment has done. Nevertheless, the Karnaphuli Fertilizer Company Ltd (KAFCO) issue in Bangladesh, the Narmada River Dam Project in India, and the Arun III Hydroelectric Project in Nepal all have been the source of heated controversy surrounding Japan's 
ODA in South Asia. About technical assistance under the JOCVs program, one of the major projects of the JICA, it is enthusiastic that JOCVs in the real sense take Japan's ODA to the grassroots level, by working hand in hand with local people, and thus advance sustainable development cooperation through sharing skills and knowledge on the ground in the nations of South Asia (Moni, 2004).

However, as the previous examples illustrate, it can fairly be questioned whether the bulk of Japan's economic assistance has been significantly efficacious in helping contribute to South Asia's sustainability attempts, or whether its fundedprojects were suitably adapted to ensure a climate favorable for investment and export promotion as well as overall economic development of the South Asian nations. On the one hand, while poverty reduction is given topmost priority with more emphasis being put on the quality of aid, Japan's ODA policy considerations regarding South Asia are oftentimes called into question due to the perception that its aid deals predominantly with large-scale infrastructure development projects, i.e., Japan's ODA is too "gigantic" and "radical." In other words, its development aid is still "much quantitative" and "less qualitative," 11 whereas aid from other donors in the South Asian nations hinges on reinforcing pro-poor policy and self-help grass-roots assistance programs towards succeeding in their poverty emancipation targets. Accordingly, in order for South Asia to reap the fullest benefits from Japanese foreign aid to this region in the years to come, the ODA strategy in dealing with the region needs a new way of thinking (Moni, 2006a). One the other hand, despite abundant donations from Japan as well as other major bilateral partners and donor organizations, most South Asian countries still have sizeable shortfalls in key areas like poverty alleviation, basic education, public healthcare and environmental hazards. Also, as Japan's cooperation with each of the South Asian countries has simply been termed as "one-sided dependency," these countries should undertake stern measures to secure prompt economic growth. Each individual nation in the region must serve as a "unique model" in order to convince Japanese taxpayers who are often anxious about the proper utilization of their money that it is worth the investment.

Table 2.

Country-wise (South Asia)* Distribution of Japan's Bilateral ODA, 2004 (Net disbursement basis; Figures in US\$ million)

\begin{tabular}{|c|c|c|c|c|c|}
\hline \multirow{3}{*}{ Country } & \multicolumn{5}{|c|}{ ODA } \\
\hline & \multicolumn{3}{|c|}{ Grants } & \multirow[b]{2}{*}{$\begin{array}{c}\text { Loan } \\
\text { assistance }\end{array}$} & \multirow[b]{2}{*}{ Total } \\
\hline & Grant aid & $\begin{array}{c}\text { Technical } \\
\text { cooperation }\end{array}$ & Total & & \\
\hline Bangladesh & 271.51 & 32.07 & 303.58 & -265.35 & 38.23 \\
\hline Bhutan & 0.55 & 9.95 & 10.51 & 0.00 & 10.51 \\
\hline India & 7.73 & 19.59 & 27.32 & -109.37 & -82.05 \\
\hline Maldives & 3.08 & 2.02 & 5.10 & 0.00 & 5.10 \\
\hline Nepal & 36.86 & 19.27 & 56.13 & 0.30 & 56.43 \\
\hline Pakistan & 41.45 & 17.06 & 58.50 & 75.60 & 134.11 \\
\hline Sri Lanka & 25.31 & 22.45 & 47.76 & 131.77 & 179.53 \\
\hline
\end{tabular}

Source: MOFA of Japan

*"Southwest Asia" in the usage of JICA 
Table 3.

Japan's ODA Disbursements to Bangladesh, 1996-2001

\begin{tabular}{c|c|c|c|r|r|c}
\hline \multirow{2}{*}{ Year } & \multicolumn{3}{|c|}{ Grant } & \multicolumn{2}{c|}{ Loan aid } & Total \\
\cline { 2 - 6 } & Grant aid & $\begin{array}{l}\text { Technical } \\
\text { Cooperation }\end{array}$ & Total & Gross & Net & Total \\
\hline 1996 & 184.77 & 30.52 & 215.28 & 105.56 & -41.25 & 174.03 \\
1997 & 169.60 & 26.83 & 196.44 & 75.99 & -66.45 & 129.98 \\
1998 & 216.35 & 22.83 & 239.19 & 93.32 & -50.14 & 189.05 \\
1999 & 204.43 & 25.04 & 226.47 & 77.68 & -102.81 & 123.66 \\
2000 & 201.96 & 40.55 & 242.52 & 161.06 & -40.90 & 201.62 \\
2001 & 169.22 & 33.06 & 202.28 & 105.29 & -76.65 & 125.64 \\
\hline
\end{tabular}

Source: MOFA of Japan

\section{Trade $^{12}$}

Although one of the major factors of Japan's economic interaction with South Asia is trade, the share of the region in Japan's global trade is negligible. There is a serious imbalance in JapanSouth Asia trade, i.e., the volume of trade of the South Asian countries with Japan currently constitutes only about 5.5 percent of that with the world (Japan External Trade Organization [JETRO], 2005). The marginal share in Japan's trade that the South Asian region has been having with Japan came down drastically in the 1990s. In spite of the fact that trading volumes have grown dramatically in Japan over the past decade, this remarkable progress of Japanese trade has however not been reflected in the South Asian trade graph. It is evident that there is an inadequate effort on the part of this region to promote new items to export to Japan. Moreover, in terms of value, the rest of the South Asian countries lag far behind India and Pakistan in exploring the export opportunities of the Japanese market. The other side of the crux is that Japan seems to be only reluctantly giving up its image of this region as one incapable of exporting little more than primary products. Despite these facts, the components that might make the South Asian region attractive in promoting its trade with Japan include cheap and rich human resources, wealth of agricultural products, good infrastructure at specific points in the region, and low inter corporate competition compared to that in the East and Southeast Asian nations. Truly, South Asia has many comparative advantages as the basis of its expanded trade relations with Japan, and a number of export items have recently come to assume a great potential.

With a particular focus on India, foreign trade is quickly spreading here, in services rather than in the traditional manufacturing sector. The information and communication technologies (ICT) industries in Japan and India complement each other. The nascent software industry is the one sector of the Indian economy that has blossomed the most from its Bangalore, Chennai and Hyderabad base in recent years. It is now searching for new customers abroad, particularly in Japan and the US. According to recent data, software exports are growing at an annual rate of 50 percent. Japan, the second largest ICT market after the US, is looking at India to outsource activities in the ICT field. In fact, Japanese industry is aware of Indian ICT capabilities in terms of execution of projects and quality processes, 
confidentiality, cost and quality focus. It has already started admitting the significance of off-shorization. Both sides have also agreed to set up a joint taskforce to identify and explore the possibility of joint ventures and stand-alone projects in the areas of broadband, mobile communication, e-governance, information security, research and development (R\&D) and ubiquitous computing. However, as Indian software exports to Japan presently account for only 3 percent of the total market, there is a necessity for unveiling future scopes for the Indian companies to interact with the leading Japanese ICT industries such as Nippon Telephone and Telegraph (NTT), Nippon Electric Company (NEC), Matsushita, Toshiba and Fujitsu. A strengthened collaborative partnership between Japan and India might bring about the fulfillment of an unparalleled ICT power (India, Japan sign pacts, 2005). Furthermore, whilst overseas firms, which endeavor to do business in India, see the country as a US $\$ 100$ billion market, especially in infrastructure sectors like electric power generation and roads, they still complain about bureaucratic hurdle and protectionism.

Another product that is an attractive prospect to the Japanese market is Bangladesh's readymade garments (RMGs). Though Bangladesh has already succeeded in introducing its RMG sector to the US as well as the EU markets, it has not yet penetrated the Japanese market (LDC Needs Protection, 2003). Also, many Japanese are unaware of it. Japan is within Asia, and nearer to Bangladesh compared to the US and Europe. It is, therefore, very logical to think that Bangladesh should have exported even more to Japan. But the reality is rather different. Bangladesh's RMG export volume to Japan fell primarily due to the poor quality of the products as seen by the Japanese market. At the same time, the RMG sector has been facing setbacks due to competitive price and late delivery of products to the agencies of importing countries. In this context, it may be noted that China currently occupies about 80 percent of Japan's total RMG market due to its geographical closeness and cultural proximity. Furthermore, it is undeniable that Chinese products are highly competitive, and their productivity is much higher in comparison to Bangladesh and other developing countries. Chinese business practice is somewhat different from others as well. Even so, Bangladesh might have prospects of increasing its apparels exports to the Japanese market, but it must have something more attractive than China for Japanese buyers. For Bangladesh, compared with Chinese productions, to enhance the present pace of growth in exporting RMGs to Japan, the following might be the best suggestions: manufacturing higher quality (in both dyeing and finishing) products and selling at a reasonable price in order to meet the demands of Japanese buyers; making the lead-time short; removing barriers of investment; engaging in promotions through exhibitions, sessions, etc., about Bangladeshi garments in Japan; building up a good business relationship with Japanese counterparts; and expanding markets. ${ }^{13}$

From the regional and global circumstances, in contrast to the volume of intra-trade among the member nations of the EU, the volume of intratrade within the SAARC countries is very insignificant. In the face of increasing competition in the world economy, while collaborative cooperation among the nations of the South Asian region has become compelling, the globalization process has practically spearheaded the concept of interdependence (Vanaik, 2004). Granted that in the South Asian region, there are a number of good possibilities for embellishing a workable economic interaction, which can attain a remarkable uplift of the socio-economic front of the teeming millions here, these potentials are being outshined by huge trade imbalances among the SAARC nations. To cite an example, there is a huge trade gap between India and Bangladesh, the annual trade deficit being over US\$1.07 billion in the first half of fiscal 2005-2006, which was US $\$ 945$ million in the corresponding period of fiscal 2004-2005; while the share of India is over $90 \%$, Bangladesh has only $8.16 \%$, Nepal $1.03 \%$ and Bhutan $0.10 \%$ (Bangladesh trade deficit, 2006).

Even supposing the South Asian Preferential Trading Agreement (SAPTA) has been in place for 
more than a decade, trading within the SAARC accounts for less than five percent of the members' total global trade simply due to differences between India and Pakistan over the disputed region of Kashmir. However, the South Asian Free Trade Area (SAFTA) agreement among the nations, effective from the start of 2004, may be seen as having the potential to pave the path to prosperity in this sub-region. While the ASEAN Free Trade Area (AFTA) established in 1992 is viewed as a dynamic model in the Asian trade scenario as well as global economy, the pact made by seven SAARC nations, which came into effect with the onset of 2006 to set up a free trade area (FTA), brings heartening news for the people of this developing region (SAARC free trade, 2006), because it promises to open the markets of all countries to each other by deepening regional trade relations, and thus bring synergy to economic growth. Although this is a good first step, there are a number of challenges toward gaining a FTA in reality.
In this connection, it may be noted that Japan has very recently proposed to create the Asian free trade agreements (FTA) covering half the world's population and four major trading powers (China, India, Japan and South Korea) (Japan Proposes, 2006). However, both scope and timetable are regarded as ambitious in the light of Japan's strained relationship with China, and the track record of one-on-one trade agreements in the region. It is manifest that Japan intends to push the East Asia economic partnership agreements (EPA) plan in order to take the lead in reinforcing the integration of the Asian economy (Govt to Push, 2006). But it is uncertain whether other Asian economies will agree on such a plan. It is also a question of whether there are merits for each EPA country, and Asia as a whole is likely to have an impact on the negotiations. In addition, some analysts hold that Japan wants a regional trade group, because it is at present concerned about falling behind China in global trade (Lack of leadership handicap, 2004).

Table 4.

Japan's Balance of Trade (by Region), 1999-2004 (US\$ million)

\begin{tabular}{l|r|r|r|r|r|r}
\hline Year & \multicolumn{1}{|c|}{1999} & \multicolumn{1}{c|}{2000} & \multicolumn{1}{c}{2001} & 2002 & \multicolumn{1}{c}{2003} & \multicolumn{1}{c}{2004} \\
\hline Total & 107,697 & 99,601 & 54,057 & 79,030 & 88,335 & 110,370 \\
North America & 60,184 & 69,242 & 56,928 & 61,027 & 56,541 & 63,577 \\
USA & 61,147 & 70,479 & 58,192 & 60,915 & 56,754 & 64,404 \\
Canada & -963 & $-1,237$ & $-1,202$ & 173 & -142 & -760 \\
EU25 & 32,957 & 32,791 & 21,136 & 18,936 & 25,280 & 31,107 \\
East Asia & 32,902 & 40,125 & 15,298 & 33,567 & 49,137 & 68,843 \\
Asian NIEs & 54,033 & 68,351 & 49,412 & 58,890 & 71,569 & 92,890 \\
Korea & 6,873 & 10,256 & 8,098 & 13,093 & 16,834 & 22,174 \\
ASEAN4 & $-1,587$ & $-3,350$ & $-7,100$ & $-3,497$ & $-4,458$ & $-3,637$ \\
China & $-19,545$ & $-24,876$ & $-27,014$ & $-21,826$ & $-17,974$ & $-20,409$ \\
Middle East & $-20,741$ & $-39,657$ & $-34,036$ & $-29,316$ & $-38,071$ & $-48,240$ \\
Central South America & 9,810 & 10,081 & 8,194 & 6,648 & 6,190 & 7,907 \\
Mexico & 2,736 & 2,828 & 2,093 & 1,972 & 1,855 & 3,013 \\
Russia & $-3,275$ & $-4,021$ & $-3,247$ & $-2,334$ & $-2,454$ & $-2,583$ \\
Africa & 1,388 & 86 & -113 & -772 & -860 & $-1,038$ \\
\hline
\end{tabular}

Source: JETRO Tokyo 
Table 5.

South Asia's Trade with Japan, 1999 (US\$ million)

\begin{tabular}{l|c|c|l|l|r|r|c}
\hline Exports/Imports & Bangladesh & Bhutan & India & Maldives & Nepal & Pakistan & Sri Lanka \\
\hline Exports to Japan & 92.76 & 0.17 & $2,554.00$ & 4.08 & 3.27 & 252.00 & 160.00 \\
Imports from & 430.93 & 23.33 & $2,755.00$ & 9.23 & 32.70 & 606.00 & 430.00 \\
Japan & & & & & & & \\
\hline
\end{tabular}

Source: MOFA of Japan

Table 6.

Intra-Regional Trade of South Asia by Country (\%)

\begin{tabular}{l|r|r|r|r|r|r}
\hline Year & 1970 & 1975 & 1980 & 1985 & 1990 & 1995 \\
\hline Bangladesh & \multicolumn{1}{|c|}{ n.a. } & 6.9 & 4.9 & 3.0 & 5.9 & 12.8 \\
India & 2.7 & 2.0 & 1.9 & 1.5 & 1.4 & 2.6 \\
Nepal & 70.3 & 67.0 & 45.7 & 34.4 & 10.0 & 14.9 \\
Pakistan & 0.9 & 4.1 & 3.5 & 2.9 & 2.6 & 2.2 \\
Sri Lanka & 8.1 & 7.8 & 6.5 & 5.2 & 5.1 & 6.1 \\
\hline Intra-South Asia & 3.5 & 3.9 & 3.2 & 2.6 & 2.4 & 3.7 \\
\hline Extra-South Asia & 96.5 & 96.1 & 96.8 & 97.4 & 97.6 & 96.3 \\
\hline
\end{tabular}

Source: SAARC Secretariat

This notwithstanding, it can be said that the center of gravity of world commerce has recently shifted to the Indian Ocean, South China Seas and the Pacific Ocean, which now carry 52 percent of the global output (Gravity of world commerce, 2006). It is anticipated that the people of Asia and its leaders, by overcoming their shortsighted attitudes, will sincerely unveil their vision of an "integrated, prosperous and poverty-free" Asia in the $21^{\text {st }}$ century. They will work together toward firing the growth engine of the region in order to expand the size of the economic pie, share it equitably, and thus close the disparity gap between the richer nations and the poorer ones. The ASEAN and the SAARC might, in particular, be regarded as the key building blocks for the integration of the entire Asia-Pacific region. Japan would, however, continue to explore the best possible approach towards trade partnership with South Asia, while watching how India is integrated into the international economy.

Conclusively, whilst South Asia is peripheral to Japan, the nation is of great importance to this economically underdeveloped sub-continent. Japan's trade with South Asia might have a chance of improving only if Japan wishes to shift a little of its trade from other regions to South Asia. Even a slight alteration could purposefully contribute to the improvement of trade of the SAARC countries.

\section{FDI $^{14}$}

Japanese multinational corporations (MNCs), with their massive FDI outflows, have been the "lead goose" in the "flying geese pattern" 15 that have spurred the economic growth of a number of 
countries in East and Southeast Asia since the mid1980s (Encarnation, 2000). In contrast, South Asia had nearly been non-existent during the rebellious years of ever-changing investment destinations. The South Asian nations, by and large, have missed out on the Japanese foreign investment boom, and have always been a negligible destination for Japanese FDI. The nationalistic attitudes to foreign investment, socio-political unrest and rampant bureaucratic corruption in almost all South Asian countries have been regarded as the major stumbling blocks that have only served to further inhibit FDI in the region. ${ }^{16}$ Although most SAARC states have already adopted economic liberalization policies and welcomed foreign investment for their rapid economic growth, there has still been a slight increase in the flows of Japanese FDI into the region. The statistical data indicate that South Asian economies have received a marginal share of Japanese FDI outflows-less than 1 percent of Japan's total FDI volume to the world. According to data, India has received the majority of Japanese FDI among the South Asian nations, followed by Sri Lanka, Pakistan and Bangladesh.

Even with a continuing economic recession in recent years, Japanese companies have expanded their investments overseas, especially to the economically vibrant destinations in East and Southeast Asia. The South Asian countries, mainly India and Bangladesh, over the years, have tried to woo Japanese investors by providing as liberal an environment as possible within their own domestic and political restraints. In search of trade and investment, the prime ministers of these nations have frequently visited Japan, but have found the Japanese business community reluctant. ${ }^{17}$ In the case of India, while several big names in Japan such as Mitsubishi, Sony, Nippon, Fujitsu, Mitsui, Hitachi, etc., have become household names, the actual inflow of Japanese FDI in India is still low, indicating a considerable degree of caution. ${ }^{18}$ Although only a few selected sectors like automobiles (Honda and Suzuki), and most recently electronics and telecommunications have received Japanese investors' attention to South
Asian countries, Japanese business people grasp a triad of investment obstacles, and their reference point very often is the offshore facilities that their expatriate community enjoys in such ASEAN countries as Malaysia, Singapore and Thailand (Ken \& Keiichi, 1997).

Indeed, the parallel of Japanese investment inflows in South Asia with those in China and the Asian NIEs is irrational, because the latter are far more alluring to Japanese investors. It is estimated that in some of these countries, Japanese MNCs have invested in "one week" what they invested in "one year" in all of the South Asian nations. One more rational contrast is Japanese investment in Vietnam, which now attracts three times more investment than in India. ${ }^{19}$ It is, in this context, necessary to explore what are the secrets for the exemplary success of Vietnam ${ }^{20}$ as one of the most attractive destinations throughout Asia for Japanese investors $^{21}$ and other global partners. First, Vietnam is endowed with rich natural resources, and a half of its 80 million people have not yet turned 30. Most of these youths are poor but relatively well educated and eager to work and learn, even at a minimum wage of just US\$38 a month. Second, the nation has made notable progress in maintaining socio-political soundness with its poor ratings on government corruption, as well as developing its macro-economic and business drifts during the past decade. Third, Vietnam has sustained a high growth rate, doubling GDP over the years. Fourth, the business climate in the country continues to improve and become more alluring for enterprises in all of the economic sectors. The reforms and improvements have been implemented in the finance and banking industry, including constructive changes in fiscal policy, such as fixing the exchange rate flexibly and making resources available for socio-economic growth. Finally, the Vietnamese economy has become increasingly integrated with the regional and global economic system. Within the frameworks of the ASEAN, the APEC and the Asia Europe Meeting (ASEM), Vietnam has also amplified its determination to join the WTO in 2006. Although a number of hurdles still exist, many can just see 
the continuation of one of Asia's most celebrated success stories. As Vietnam has widely been praised as a successful model, the South Asian nations should learn lessons from it.

It may further be emphasized that among the BRICS (Brazil, Russia, India, China, and South Africa), India has a larger middle class, as cited before, than the ASEAN, possesses an inexpensive but highly skilled labor force, can provide an opportunity to hedge risks from relying too much on China, as well as having a people with very positive attitudes toward Japan. But it is a common question among those involved is why Japanese companies still have not come to India. Despite some institutional barriers, a number of Korean firms with their huge FDI inflows have already managed to become successful here. In fact, most of the successful foreign firms in India have really been forward-looking by putting forth a large amount of funds into the initial investment. ${ }^{22} \mathrm{~A}$ strong commitment from the top-level management makes this kind of large-scale initial investment possible. Another key factor leading to success in India is the capacity to maintain a high level of quality in human resources. However, it may further be asked what makes the successful foreign firms distinct from the unsuccessful Japanese ones. In order to find the answers to these questions, a rigorous field study in India needs to be conducted. This research, however, finds that the recently increasing conflicts of interest between Japanese and Indian joint venture (JV) partners have made the Japanese even more cautious. ${ }^{23}$

This notwithstanding, there are some Japanese JV enterprises in India that have proved to be successful. The successful collaboration between the Indian Maruti Udyog Ltd. (MUL) ${ }^{24}$ and the Japanese Suzuki Motor Corporation does offer a number of valuable insights on the adaptability of Japanese work practices in an Indian organization. In summary, Maruti-Suzuki JV provides a unique combination of long-term finance, technology, training, know-how, managerial expertise and marketing experience in South Asia. Although it has recently experienced some constraints, ${ }^{25}$ it is also evident that there is a little difficulty in adopting
Japanese management practices in Indian JV with the Japanese as an equal partner. The success story of this JV company has really revolutionalized the Indian automobile industry, ${ }^{26}$ while at the same time demonstrating that the Japanese management has some appeal, if not an universal one, outside Japan's borders. This example can be a forerunner for other JV that have sprung up in the liberalization phase.

There are a number of reasonable justifications as to why South Asia could/should be an attractive "hub location" for FDI flows by Japanese MNCs in particular and global flows of FDI in general. First of all, the current global trend of economic reforms is much in evidence in South Asia. In recent years, the nations of this region have drastically changed the entire spectrum of their industrial policies and attitudes toward FDI. Another most significant aspect is the huge market potential of South Asia, a region of one fifth of the world's population. Half of the South Asian nations being bracketed as the LDCs enjoy easy global market access. As cited before, India alone has a population of more than 1.2 billion. The closeness of China to the region is also a plus point since the demand for a number of goods such as automobiles and other white goods is growing there. Consequentially, the industries could be set up to cater to the demands in China, in addition to those in the region. The availability of cheap and skilled computer literate human resources in the region suggests future opportunities as well. The entire energy sector, including petroleum, natural gas, power and captive coal mining, offers exciting possibilities. With regard to the intra-regional flows of FDI, the South Asian region also possesses prospects. Summarily, there is currently an excellent scope to fuel FDI in numerous sectors in South Asia. Consequently, Japanese MNCs could diffuse their involvement in the South Asian growth processes.

Whilst South Asia has a number of inspiring potentials for Japanese enterprises, it is worth asking why these do not materialize. The differences in variability of Japanese MNCs regarding population and income of host countries 
do not explain the neglect of the South Asian countries by them. As the export orientation of Japanese investments is actually responsive to the geographical distance between home and host countries, Japanese MNCs prefer to invest in neighboring countries. It is also important to ask what forces internal to Japan are driving Japanese firms to East and Southeast Asia, and why do firms invest in these specific Asian locations. The framework of this analysis may be based on three specific concerns. First, rising cost conditions in Japan are motivating firms to seek alternative locations. Second, globalization of the economy is creating pressures to seek production locations that minimize cost, while effectively serving customer needs. Third, and in the context of the first two factors, a variety of country characteristics (attractiveness of the domestic market, production conditions, and incentives for FDI) as well as rivalry between firms lead to location choices. Nevertheless, as Japanese MNCs are becoming growingly global in their future orientations, the comparative prominence of geographical distance and cultural proximity as cardinal determinants of their location might diminish, and they will be more inclined to diversify their ventures into South Asia. Compared to other investing nations, while Japan has remained somewhat hesitant, now is the time to seize South Asia's opportunities. Above all, there is every reason to believe that Japanese investors would further make more investments in South Asia to reduce the trade gap, taking diverse advantages of the region's encouraging FDI climate.

South Asian nations can now take full advantage of the ongoing economic situation in Japan, through relocating the Japanese "sunset industry," i.e., small and medium-sized enterprises (SMEs), in the respective country with JVs, because the traditional keiretsu [collaborating enterprises] structure has almost failed in Japan. The subcontracting keiretsu framework, which was a driving force behind Japanese industrialization, has become useless due to the stronger yen and higher labor cost, compelling big companies to buy back spares from outside. As a result, most SMEs in Japan that used to supply spares for over the decades to heavy companies like Toyota, Nissan and Hitachi are now in the doldrums. It is estimated that in recent years, at least 70 percent of Japanese SMEs have been looking for outside partners for the sake of their survival (Small business checks in, 2004). The countries of South Asia with their cheaper labor forces can take the opportunity to attract these SMEs right now.

Albeit globalization has resulted in a vast increase in FDI, and the greater inflow of FDI has in turn boosted deeper integration of world economies, South Asian countries are still not in a position to turn back from FDI due to a number of severe administrative drawbacks and managerial shortcomings. But the region now desperately needs to concentrate on the improvement of its investment environment, and it must develop a comprehensive common investment policy. It is high time that they at least agree on some fundamental policy frameworks so that there is not much unfair competition among themselves. The other world regions have already realized the implications of regional cooperation, and have taken initiatives accordingly. As a result, they have now started receiving rewards. The South Asian region needs to learn from these experiences. Otherwise, it will lag further behind, and the potential of huge FDI inflows here in South Asia will not be harnessed. Simply providing incentive packages and liberalization measures will not automatically attract FDI, nor has FDI always proved to have a positive impact on economic growth of a country. To ensure that it does, it is necessary that South Asian governments retain the right to choose the types and directions of FDI they attract, according to their own necessities. It is redundant to say that in this new epoch of globalization, the investors enjoy enough flexibility, and they may easily transfer their destination when they face any kind of hurdle that adversely affects their businesses. Hence, to attract Japanese investors with an extensive amount of FDI outflows in the near future, South Asian nations must undertake concerted, aspiring and spirited efforts, by removing all FDI impediments sooner rather than later. 
Table 7.

FDI Inflows by Host Regions and Economies (US\$ million)

\begin{tabular}{l|l|l|l|l|l|l|l}
\hline $\begin{array}{l}\text { Host Region / } \\
\text { Economy }\end{array}$ & $1989-94$ & 1995 & 1996 & 1997 & 1998 & 1999 & 2000 \\
\hline World & 200,145 & 331,068 & 384,910 & 477,918 & 692,544 & $1,075,049$ & $1,270,764$ \\
\hline LDCs & 1,430 & 2,016 & 2,450 & 2,976 & 3,679 & 5,176 & 4,414 \\
Share in World & $0.71 \%$ & $0.61 \%$ & $0.64 \%$ & $0.62 \%$ & $0.53 \%$ & $0.48 \%$ & $0.35 \%$ \\
FDI (\%) & & & & & & & \\
\hline Asia & 37,569 & 575,293 & 94,351 & 107,205 & 95,599 & 99,728 & 143,479 \\
Share in World & $18.77 \%$ & $22.74 \%$ & $24.51 \%$ & $22.43 \%$ & $13.80 \%$ & $9.28 \%$ & $11.29 \%$ \\
FDI (\%) & & & & & & & \\
\hline $\begin{array}{l}\text { South Asia* } \\
\text { Share in World }\end{array}$ & $0.41 \%$ & $0.89 \%$ & $0.96 \%$ & $1.03 \%$ & $0.51 \%$ & $0.28 \%$ & $0.24 \%$ \\
FDI (\%) & & & & & & & \\
\hline
\end{tabular}

Source: UNCTAD

*Excluding Bhutan, because of non-availability of data for required years.

Table 8.

South Asia's Major Sources of FDI Inflows (US\$ million)

\begin{tabular}{l|c|l|l|l|c}
\hline Source / Country & Bangladesh $^{\mathrm{a}}$ & India $^{\mathrm{b}}$ & Nepal $^{\mathrm{c}}$ & Pakistan $^{\mathrm{d}}$ & Sri Lanka $^{\mathrm{e}}$ \\
\hline Japan & $3(7.6)$ & $5(4.4)$ & $6(6.1)$ & $3(15.0)$ & $4(11.6)$ \\
USA & $1(29.5)$ & $1(22.1)$ & $7(1.1)$ & $1(41.6)$ & - \\
Germany & $8(1.9)$ & $6(3.8)$ & - & $4(6.2)$ & $5(7.0)$ \\
UK & $2(13.9)$ & $3(7.6)$ & $5(6.2)$ & $2(22.7)$ & $9(1.4)$ \\
France & - & $9(2.5)$ & - & $5(2.2)$ & - \\
Korea & $6(2.8)$ & $4(4.5)$ & - & $8(1.6)$ & $1(32.7)$ \\
Hong Kong & $4(7.5)$ & - & $10(2.1)$ & - & $3(11.9)$ \\
Singapore & $5(5.9)$ & - & - & - & $6(6.4)$ \\
Malaysia & - & $8(2.75)$ & - & - & - \\
Australia & - & $7(3.0)$ & - & - & $2(15.0)$ \\
Mauritius & - & $2(10.4)$ & - & - & - \\
China & $9(1.3)$ & - & $4(7.5)$ & - & - \\
Netherlands & - & - & - & $6(1.7)$ & - \\
Italy & - & $10(2.2)$ & - & - & - \\
Bermuda & - & - & $2(14.6)$ & - & - \\
Philippines & - & - & $3(9.6)$ & - & - \\
Denmark & - & - & $8(3.1)$ & - & - \\
New Zealand & - & - & - & - & - \\
UAE & - & - & - & - & $8(1.6)$ \\
Sweden & - & - & - & - \\
\hline
\end{tabular}

Source: SAARC Secretariat

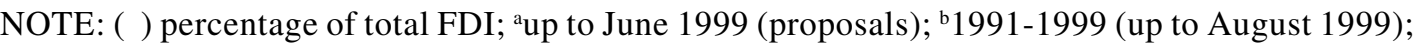

cas of December 1995 (proposals); ${ }^{\mathrm{d}}$ 1998-1999 (July-March); ${ }^{\mathrm{e}}$ 1978-1995 (in operation as of December 1995). 
Table 9.

Japanese FDI in India, 1991-2001 (US\$ million)

\begin{tabular}{ccc}
\hline Year & Investments & Actual Inflows \\
\hline 1991 & 21.5 & 2.3 \\
1992 & 233.2 & 27.4 \\
1993 & 84.0 & 26.4 \\
1994 & 127.8 & 87.9 \\
1995 & 482.3 & 72.3 \\
1996 & 432.8 & 87.5 \\
1997 & 531.5 & 164.8 \\
1998 & 324.8 & 197.6 \\
1999 & 379.7 & 151.3 \\
2000 & 192.5 & 158.5 \\
2001 & 78.2 & 101.8 \\
\hline Total & $2,888.3$ & $1,077.8$ \\
\hline
\end{tabular}

Source: Government of India

Table 10.

FDI Inflows in SAARC Countries (US\$ million)

\begin{tabular}{l|c|c|c|c}
\hline Year & $1980-1985$ & 1990 & 1995 & 1998 \\
\hline Bangladesh & -0.1 & 3 & 2 & 317 \\
Bhutan & n.a. & n.a. & n.a. & n.a. \\
India & 62.0 & 162 & 1,964 & 2,258 \\
Maldives & -0.3 & n.a. & 7 & 7 \\
Nepal & 0.2 & 6 & 5 & 9 \\
Pakistan & 75.0 & 244 & 719 & 497 \\
Sri Lanka & 42.0 & 43 & 53 & 345 \\
\hline
\end{tabular}

Source: UNCTAD

\section{FUTURE OUTLOOK}

In the face of today's competitive world economy, in order to boost economic cooperation among the nations across Asia (especially South Asia and Southeast Asia), a "regional block building" is essential. The creation of a "Pan-Asian Forum" like the EU and the North Atlantic Free Trade Agreement (NAFTA) is now being vigorously emphasized. Through the establishment of such an organization, all the member nations could reap benefit from each other. In this respect, it can critically be claimed that, while $21^{\text {st }}$ century will be the "Asian Century," and the West always looks toward the East, and more importantly, everyone requires a "backyard" of the surrounding countries for economic growth, Japanese business planners unluckily do not find such within Asia. They 
most often look at the West for marketing of their products, defying the fact that there are huge markets emerging in Asia because of the rise in number of middle class people. Thus, Japan may now be called upon to undertake further drive to form a similar platform for strengthening economic cooperation and revitalization of the hinterland region. The pan-Asian FTA, as recently proposed by Japan, can be viewed as the future of Asia. However, Japan ought to take active initiatives so that it could open up new growth avenues for the Asian economies, particularly the South Asian ones.

Beyond the economic aspects, Japan's diplomacy regarding other parts of Asia has been undergoing a phenomenal shift in recent times. Tokyo today seems to be in the process of redefining its strategic future and priorities. It is stimulating to know that Japan is presently taking a keen interest in cooperating for South Asia's economic prosperity, and has also ratified a new approach in its security and defense policies to the nations of South Asia. According to a recent report published in a Japanese conservative newspaper (Japan bypasses China, 2006), the MOFA of Japan has already began to reorganize and reinforce itself when the Parliament Session ended in June 2006. It is preparing to create a special "South Asia Department," ${ }^{27}$ designed to coordinate diplomacy with India, and monitor China's growing regional influence. The new Department will also be responsible for focusing greater attention on Pakistan and other South Asian nations. While it comes some weeks after the Bush administration merged the State Department's Bureau of South and Central Asian Affairs into a single unit, the timing of Japan's latest effort toward stepping up engagement with South Asia is really important. The initiative has come at a time when the South Asian trade balances are improving, making them well placed to take advantage of Japan's constructive partnership with them. The geo-political locus of South Asia also underwent a sudden change in November 2005 when Nepal successfully tied Afghanistan's SAARC membership to observer status for China.
While the strategic contours of Beijing's South Asia policy are becoming clearer, Japan's former Prime Minister Junichiro Koizumi agreed with his Indian counterpart to work for a closer strategic and trade partnership following moves by India to build a compact tie with China (Japan, India share, 2005). Tokyo was motivated to build an organized link with New Delhi in the light of China's increasing friendship with India, as well as to face China's growing clout in a dramatically changing Asia. One Japanese diplomat used the phrase "hop step jump" to describe the recent visits of Koizumi and his Foreign Minister Taro Aso to India and the return visit of India's Prime Minister Manmohan Singh to Japan, when Tokyo was hopeful that the two sides would be willing to "jump" to a new level of understanding. From the Indian viewpoints, the growing engagement with Japan makes good sense, because the politico-strategic dimension in their relationship is relatively new, while the two countries have dealt with each other on the economic front for more than half a century. However, how to remain strategically engaged with Japan while also developing a strategic relationship with China and South Korea is a serious diplomatic dilemma that India will have to cope with. New Delhi sees Japan as a major support to its UN bid because of Koizumi's closer relations with US President George Bush, but will be cautious not to jeopardize the ardent relationship with Beijing. Very briefly, it is apparent that diplomatic attempts to redefine historical power balances throughout Asia are continuing. In particular, they are reshaping a "new dynamism," with continuous dialogues between Japan and South Asia on forging economic, political and strategic alliances.

It should be mentioned that current Japanese Prime Minister Shinzo Abe is also fervent about India. In his book (Abe, 2006), published when he had been the Chief Cabinet Secretary in the Koizumi administration, Abe said that it would not be surprising if, in another 10 years, Japan-India relations overtake Japan-US and Japan-China relations. He also wrote that it is of crucial importance to Japan's national interest that the country would further strengthen its ties with India. Although it is not yet convinced 
how Abe's vision will come true, a more positive phase in the relationship between Japan and South Asia under his regime is expected.

Under this changing scene, South Asia right now urgently needs to exploit its potentials, by deepening and diversifying the region's current involvement with Japan. The nations of the region should not miss out on the opportunity of being an active part of Japan's recent awakening and its renewed interest in engaging itself with the region. But without efficiently curbing pervasive corruption, upholding social justice, and stressing harmonious development by practicing democracy for the sake of nation building, South Asia will doubtlessly be in peril of destroying its prosperous tomorrow. Moreover, South Asian governments lack steadfast foreign policy stances. Their hesitant rapprochement as well as wary, low profile or slow-moving diplomacy is hurting the region's economy. Again, very sad to say, with the advent of two nuclear powers, South Asia has today become a special theater of concern not only for Japan but also for the international community. However, the real war that Pakistan and India should fight is not one involving "nuclear weapons," but rather one against the "chronic poverty" of this region, a home to twothirds of the world's poor with one in three surviving on less than US\$1 a day. There is also a wider array of disparities in the distribution of economic resources among the South Asian nations. Beyond politico-economic issues, there are still some controversial socio-cultural issues that divide them. But Mahatma Gandhi, a universally acclaimed leadership personality in whom India as well as South Asia can genuinely take pride, provided an example of a good neighborly policy. In his words of wisdom, "One who serves his neighbors serves all the world." Regrettably, the political leaders of India and other South Asian nations have neither followed such valuable counsel nor learned lessons from history nor gathered experiences from the booming neighbor regions. In this fast moving world, the ultimate fate of South Asia's millions of ordinary people lies in the hands of their leaders, who must prove visionary leadership with true will and changed mindset.

In light of its changed ODA Charter, Japan is already set to make a historic economic policy decision, shifting its foreign aid focus away from China to India. Nonetheless, as it is evident that ODA alone will not be adequate to meet the emerging needs of India and other South Asian economies, and in view of the uncertainty about the continued smooth flow of ODA from Japan in future, it is indispensable to them to look for the alternative sources for funds, and captivate FDI on a large scale. Looking at the successful stories of some East and Southeast Asian nations, it is clear that an expanded role of FDI shouldered by Japanese MNCs could valuably contribute to poverty reduction, human security and sustainable development in low-income and low-saving economies such as those in South Asia. It is, therefore, earnestly hoped that South Asian countries will diligently work together for the improvement of their domestic political and socioeconomic situations in order to attract a grater share of FDI inflows made by Japanese entrepreneurs in the days to come.

While some analysts argue that Japan's relative economic decline and China's rapid ascent have altered the dynamics of Asian regionalism, it should be remembered that the real resurgence of Asia (including China) began with Japan's "economic miracle." To be more explicit, Japan's ODA, provided mostly in the form of loans to some Asian countries, assisted with infrastructure building, a base for economic growth, and supported projects of private enterprises, significantly resulting in "dramatic development" in a number of countries throughout this region, which are today known as the "little dragons" or "emerging tigers." More relevantly, Japan is still the world's second largest economy, and its economy is currently seven times the size of China's. Despite the endless stories about its economic slump in recent years, Japan remains a nation of global significance, and a major power vitally important not only to South Asia but also to the rest of the world. Besides, the strong "JapanUS Alliance" as well as their increasing 
collaborative engagement in Asia is an influential factor. While some further suggest that the SAARC member states should take full advantage of the achievements of China, as their immediate neighbor, it must be acknowledged that Japan, with its mammoth foreign aid programs, has been a "tested, trusted and longstanding" ${ }^{28}$ development partner to all the South Asian impoverished economies. Japan truly wishes South Asia to become a "just, equitable and prosperous" region with a sustained pathway to development. So, it must be stressed that South Asia's "look East policy," which had partly been evolved to attract FDI from the East and Southeast Asian nations over the years, should now be more stable, productive and speedy, and be concentrated on Japan.

\section{CONCLUSION}

South Asia has frequently been regarded as a "conflict-prone region," or "Kashmir, a nuclear flashpoint." But there is no denying the fact that the nations of this region, amongst the worst victims, ultimately were able to loosen the two centuries old colonial stronghold after a heroic struggle for independence. The end of the Cold War has indeed brought a number of noteworthy repercussions to South Asia, which might genuinely appeal Japan's attention to be more responsive to the region's changing needs. While most South Asian countries now have democratically elected governments, they have come to understand that their earlier restrictive economic strategies will not be in tune with the changing realities of the globalization process. They are now realizing that they must be able to settle some of their deep differences over the political issues to enhance economic cooperation with each other. The seven member states of the SAARC also understand that the region desperately needs a greater integration to marshal its resources, and help stimulate development that will offer its citizens better lives as well. They have, therefore, vigorously opted for economic liberalization measures. Under these programs, they now welcome FDI as one of the most important means to achieve economic growth.

With particular focus on India, because of the nation's sustained economic progress in recent years, its technical excellence globally, its diplomatic activism, especially as a major player in the Group of 20 developing countries, as well as its push to secure a G4 membership bidding to become a permanent member of the UNSC, a number of countries are paying increasing attention to India, and Japan is no exception. While India is already one of the major players in Asia, the nation's rising prominence on the world stage should be taken into consideration. In the future politics of Asia, India and Japan could be strong and reliable partners, as both countries fundamentally share common values such as democracy, press freedom, market economy and so on. Both nations would be able to work hand in hand to nurture such values in a peaceful and stable way in Asia. It may also be stressed that with Japan and India so bonded, China might extend strategic space to these two powers, and thereby pave the way for Asian security. But for that to happen, Japan ought to recognize how much India has changed, and India needs to act like a "responsible power" with its growing strengths.

It may reasonably be assumed that Japan's foreign policy radar will orient itself toward building the cohesive strategic ties with South Asia to keep with changing times and trends. Because a strategic economic partnership between Japan and South Asia has many potentials, Japan ought to help effectuate it to the fullest. Japan and South Asia would share strategic interests in concretizing what may be called an "arc of Asian prosperity," as well as dealing with such global threats and challenges as environment, energy, terrorism and the UN reform. Tokyo would positively benefit from continuing to recognize South Asia's strategic weight in a fast moving Asia, and showing evergreater interest in increasing its utmost help to the region so that it can rise to a plethora of hurdles of global competition.

Seemingly, Tokyo is determined to extend its hands of cooperation with South Asia, and it has 
already outlined a roadmap to devote itself to this goal. What is now necessary is to escalate it toward addressing the deficiencies in the institutional framework of relationship between the two sides. It may fairly be concluded with optimistic aspiration that Japan may take South Asia rather seriously to make it a "flourishing region," applying the nation's "know-how" from its past admirable accomplishments in case of East and Southeast Asia. The ongoing multifaceted ties, especially in investment and trade ones, will continue to grow from strength to strength not only to the benefit of both peoples, but also to contribute to the regional solidarity and integration, helping connect South Asia with Southeast Asia in particular and the whole Asian landscape in general in the years ahead.

\section{ACKNOWLEDGEMENTS}

The author gratefully acknowledges sincere assistance of the concerned personnel at the MOFA and METI of Japan, JICA, JBIC, JETRO and the Embassies of South Asian countries here in Tokyo, who had been cooperative enough to provide him with useful information and reference materials. He also extends his gratitude to the anonymous referees for their valuable comments/ suggestions on the earlier manuscript of this article.

\section{NOTES}

${ }^{1}$ Quoted in Prueher (1997).

2 "Economic cooperation" refers to the practice of people or greater entities working in common with commonly agreed upon economic goals, and possibly methods, instead of working separately in competition. "Cooperation" is the antithesis of "competition," the need or desire to compete with others in a very common impetus that motivates individuals to organize into a group and cooperate with each other in order to form a stronger competitive force.

3 "Economic integration" is a term that is often used but rarely defined. It is popularly used to describe how different aspects between economies are integrated. In the 1960s, the Hungarian Economist Bela Balassa wrote the basics of this theory. As economic integration increases, the barriers of trade between markets lessen.
The most integrated economy today, between independent nations, is the European Union (EU) and its euro zone. The degree of economic integration can be categorized into the following six stages: preferential trading area, free trade area, customs union, common market, economic and monetary union, and complete economic integration.

${ }^{4}$ The basic differences between "market-driven economy" and "politically-driven economy" is that under a marketdriven economy, goods and services are apportioned by bids among prospective buyers, while goods and services are apportioned solely by political decisionmakers under a politically-driven economy.

5 In International Relations, "regionalism" (or "regionalization") is actually the set of processes that lead states to work together in an international framework on a regional scale. Regionalism also constitutes one of the three constituents of the international commercial system along with multilateralism and unilateralism. It refers to the expression of a common sense of identity and purpose combined with the creation and implementation of institutions that express a particular identity and that shape collective action within a geographic region (Fawcett, 1995; Nye, 1968).

${ }^{6}$ As mentioned in the previous section, the earlier Japanese ODA loans to India and Pakistan were a part of its Cold War Strategy. So, the end of the Cold War should naturally have lessened South Asia's strategic importance to Japan. But the opposite happened, for the following two intrinsic reasons: First, within the contemporary global strategic setting, India has been working to strengthen its ties with the US and other major powers with which it had limited engagement during the Cold War era, and its recent advances in defense cooperation with the US are of particular note. As Japan perceives that this Indian initiative might contribute to peace and stability in Asia, the nation is helping to foster stability and prosperity in the AsiaPacific through the Japan-US Alliance. Second, Japan, at the same time, firmly maintains that improvement in Pakistan-India relations is vital for Japanese companies here to be able to perform durable economic activities. Such development will make the Indian market more attractive for investors, and thus contribute directly to the economic growth of India itself as well as the region as a whole.

${ }^{7}$ NAM is an international organization of 115 states that consider themselves not to be formally aligned with or against any major power bloc.

${ }^{8}$ Lured by estimates that India's huge middle class is the size of the population of the US or several European countries combined, makers of everything from corn flakes to cars flocked here after free-market reforms in 1991 began to transform the economy. Now, with 
inventories mounting, multinationals are discovering that the middle class of India is not the middle class of the West, by a long shot. In much of the West, a middle class family has a mortgage, car, personal computer and enough savings for an annual vacation. In India, middle class is a family that can afford to eat a balanced diet, send the children well clothed to school and buy a black and white television.

${ }^{9}$ While a recent survey conducted by the Japan External Trade Organization (JETRO) shows that the South Asian nations are competitive in terms of labor costs, other factors such as telecom expenses, transportation costs and times to major ports like Yokohama and Los Angeles, and taxation rates are less competitive than other cities in China or even Vietnam.

10 Since 1993, through the "Japan-SAARC Special Fund," Tokyo has recognized the importance of the SAARC as an organization that can provide a framework for stability and prosperity in the South Asian region.

${ }^{11}$ As described earlier, in order to meet the newfangled global problems, especially the Millennium Development Goals (MDGs) adopted by the UN, the government of Japan has however recently brought a remarkable reform toward its ODA Charter in a more explicit outlook, defying the nation's prolonged economic recession and reluctant domestic atmosphere.

${ }^{12}$ See Moni (2006b).

${ }^{13}$ However, in the post multi-fiber agreement (MFA) period, the prime question is whether Bangladesh could continue to maintain its present growth impetus driven by rapid export expansion, or will the country suffer a "trade shock" with disadvantageous consequences for its economy? Even so, in order to overcome the present stagnant situation, Bangladesh and other South Asian nations need to carefully investigate the changing patterns of Japanese demands, and to observe how they could meet those demands.

${ }^{14}$ See Moni (2005).

${ }^{15}$ The V-shaped "Flying Geese Model" is a perception of Japanese scholars upon the technological development in some East and Southeast Asian countries, including South Korea, Taiwan, Singapore, Malaysia and Thailand, viewing Japan as a leading power. Under this dynamic process of regional economic development, leading countries with a comparative advantage over the others first made a shift towards more capital and technologyintensive industries, with successive economies then moving up the ladder. This distinctive model was developed in the 1930s, but gained wider popularity in the 1960s after its author, Akamatsu, published his ideas (Akamatsu, 1962).

${ }^{16}$ The problem is not one-sided however, because the foreign investors including the Japanese ones are often seen highly demanding without exploring the existing relative advantages of some South Asian countries as potential investment locations.

${ }^{17}$ It should, however, be mentioned that considering Japan's current reluctant stance, South Asia might naturally look for other sources of FDI. As the newly industrializing economies (NIEs) have funds to invest overseas, South Asian nations now have alternatives in Asia to consider, beyond Japan.

${ }_{18}$ Nonetheless, Mitsubishi Corporation has recently identified India as one of the six emerging markets worldwide in which this conglomerate plans to develop its business operations from a long-term perspective (Mitsubishi puts India, 2003).

${ }^{19}$ In recent years, Japanese combined investment in India, Sri Lanka, Pakistan and Bangladesh has somewhat increased, but in proportion to Japanese investment in other Asian countries, the South Asian share is indeed insignificant.

${ }^{20}$ In Vietnam, FDI inflows have reached a record high US\$10.2 billion, far exceeding the 2006 target of US\$6.5 billion. This Asian upstart is also challenging China in light manufacturing and pulling in nearly as much foreign investment as India.

${ }^{21}$ Among Vietnam's 62 trading and investment partners, Japan is the largest, endeavoring to make a significant contribution to modernizing the country.

${ }^{22}$ For example, Korea's LG and Samsung have managed to gain a huge share of the Indian market in a very short time by their use of a large-scale initial investment. The advantages of a large-scale initial investment comprise not only a faster attainment of brand image but also the ability to achieve an upper hand in negotiations with local government bodies.

${ }^{23}$ In this example, it may be observed that the bitter experience of Toshiba Corporation in trying to withdraw from Toshiba Anand Batteries, and the reluctance of the Indian government to allow Suzuki to expand and modernize Maruti have concealed the image of India as an investment market. A similar imbroglio involves another of Suzuki's Indian partners, the Madras-based TVS, one of the leading two wheeler manufacturers, in that Suzuki not only wants to increase its stake from the current 26 percent in the company's equity, but also wishes to play a key management role, as it does with Maruti.

${ }^{24}$ Established in February 1981 (though actual production commenced in 1983) it is one of India's leading automobile manufacturers and the market leader in the car segment, both in terms of volume of vehicles sold and revenue earned-18.28 percent of the company is owned by the government, and 54.2 percent by Suzuki of Japan. The Indian government held an Initial Public Offering of 25 percent of the company in June of 2003.

${ }^{25}$ For instance, the relationship between the Indian government, under the United Front (India) coalition, 
and Suzuki Motor Corporation over the JV was a point of heated debate in the Indian media till Suzuki gained the controlling stake. The high profitability of the JV, which had a near monopolistic trade in the Indian automoble market and the nature of the partnership built up till then were the underlying reasons for most issues. ${ }^{26}$ Through 2004, Maruti has produced over 5 million vehicles that were sold in India and various other countries, depending upon export orders. The success of the JV actually led Suzuki to increase its equity from 26 percent to 40 percent in 1987 , and further to 50 percent in 1992.

${ }^{27}$ Prime Minister Toshiki Kaifu, following his visit to South Asia in 1990, also initiated several measures to promote a wider exchange and better understanding between two sides. Towards this end, a platform named "South Asian Forum (SAF)" was created in the Foreign Ministry in the following year. The forum, however, later became ineffective because of Tokyo's increased attention to other parts of Asia.

${ }^{28}$ The year 2002 marked the $50^{\text {th }}$ anniversary of the establishment of Japan's diplomatic relationship with India, Pakistan, and Sri Lanka, and the $30^{\text {th }}$ celebration with Bangladesh.

\section{REFERENCES}

Abe, S. (2006). Utsukushii kuni e [Towards a beautiful country]. Tokyo: Bungei Shunju.

Akamatsu, K. (1962). A historical pattern of economic growth in developing countries. Journal of Developing Economies, 1(1), 3-25.

Asian Development Bank [ADB]. (2005). Asian economic cooperation and integration: Progress, prospects, and challenges. Manila: Asian Development Bank.

Bangladesh trade deficit with India widens. (2006, April 2). Hindu, p. A4.

Bharucha, R. (2006). Another Asia: Rabindranath Tagore and Okakura Tenshin. New Delhi: Oxford University Press.

Blechinger, V., \& Legewie, J. (Eds.). (2000). Facing Asia: Japan's role in the political and economic dynamism of regional cooperation. Munich: Iudicium Verlag.

Borthwick, M. (1998). Pacific century: The emergence of modern Pacific Asia. Boulder, CO: Westview Press.
Buzan, B. (2002). South Asia moving towards transformation: Emergence of India as a great power. International Studies, 39 (1), 1-24.

Dillon, D. R. (2005). US strategic objectives in South Asia. Heritage Lecture, no. 889, at the Asian Studies Center, The Heritage Foundation, Washington, D.C.

Encarnation, D. J. (Ed.). (2000). Japanese multinationals in Asia: Regional operations in comparative perspective. New York: Oxford University Press.

Esho, H. (1994). Kaihatsu to enjo: Minami Ajia, kouzou choysei, hinkon [Development and aid: South Asia, structural adjustment and poverty]. Tokyo: Dobunkan.

Fawcett, L. (1995). Regionalism in historical perspective. In L. Fawcett \& A. Hurrell (Eds.), Regionalism in world politics: Regional organization and international order (pp. 9-36). Oxford: Oxford University Press.

Fukushima, A. (1999). Japanese foreign policy: The emerging logic of multilateralism. New York: St. Martin's Press.

Govt to push Asian EPA talks. (2006, April 5). Yomiuri Shimbun [Yomiuri News], p. A1.

Graham, E. (2005). Japan's sea lane security, 1940-2004: A matter of life and death? London \& New York: Routledge.

Gravity of world commerce shifted to ASEAN, SAARC. (2006, January 21). Financial Express, p. A1.

Hirose, T. (1996). Japan in a dilemma: The search for a horizontal Japan-South Asia relationship. In P. C. Jain (Ed.), Distant Asian neighbours: Japan and South Asia (pp. 28-44). New Delhi: Sterling Publishers.

India, Japan sign pacts for collaboration in ICT sector. (2005, August 25). Financial Daily, p. A2.

Japan Bank for International Cooperation [JBIC]. (2003). JBIC annual report 2003. Tokyo: Japan Bank for International Cooperation.

Japan bypasses China to look at India. (2006, April 6). Sankei Shimbun [Sankei News], p. A1. Japan External Trade Organization [JETRO]. (2005). Japanese trade in 2004. Tokyo: Economic Research Department, Japan External Trade Organization. 
Japan, India share strategic agenda, claims Koizumi. (2005, April 30). Japan Times, p. A1.

Japan International Cooperation Agency [JICA]. (2005). JICA annual report 2005. Tokyo: Japan International Cooperation Agency.

Japan proposes region-wise free trade pact. (2006, April 4). Industry Week, p. A8.

Japan urges nuclear states to take decisive step of ratifying CTBT. (2005, September 26). Japan Policy \& Politics, p. A2.

Japan wants Pakistan to stop producing missiles: FM pledges to examine loan resumption. (2004, August 12). Dawn, p.1.

Japan's direct investment in China rises to record US\$6.5 billion last year. (2006, April 3). Mainichi Daily News, p.1.

Katzenstein, P. J. (1997). Asian regionalism in comparative perspective. In P. J. Katzenstein \& T. Shiraishi (Eds.). (pp. 1-44). Network Power: Japan and Asia . Ithaca, NY: Cornell University Press.

Kawabe, I. (1994). Kokuren to Nihon [United Nations and Japan]. Tokyo: Iwanami Shoten.

Kawai, M. (2005). East Asian economic regionalism: Progress and challenges. Journal of Asian Economics 16(1), 29-55.

Ken, A., \& Keiichi, B. (Eds.). (1997). Nihon kigyou to chokusetsu toushi: Tai Ajia toushi no aratana kadai [Japanese enterprises and direct investment: New issues for investment in Asia]. Tokyo: Keiso Shobo.

Kobayashi, Y.(1991, April). Nihon: Sai Ajia-ka [The re-Asianization of Japan]. Foresight, 44-46.

Lack of leadership handicap in FTA race. (2004, September 27). Nikkei Weekly, p. A5.

LDC needs protection in EU markets, RMG export volume to Japan decreases. (2003, March 6). Bangladesh Observer, p. A10.

Ministry of Foreign Affairs [MOFA]. (2002). Japan's ODA annual report 2002. Tokyo: Economic Cooperation Bureau, Ministry of Foreign Affairs.

Ministry of Foreign Affairs [MOFA]. (2004). Diplomatic bluebook 2004: Efforts to tackle various global issues to promote human security. Tokyo: Ministry of Foreign Affairs.
Mitsubishi puts India among six key markets. (2003, July 3). Financial Express, p. A1.

Moni, M. H. (2004). Development cooperation in practice: Japan Overseas Cooperation Volunteers (JOCV) in Bangladesh. An unpublished master's thesis, Hitotsubashi University, Tokyo, Japan.

Moni, M. H. (2005, November 21-23). Japanese FDI in South Asia: Limits and possibilities. Paper presented at the $16^{\text {th }}$ international conference of the New Zealand Asian Studies Society (NZASIA), organized by the Department of East Asian Studies, University of Waikato, Hamilton, New Zealand.

Moni, M. H. (2006a). Japan's ODA to Bangladesh: Lessons learned and strides forward. Journal of International Development Studies, 15(1), 117-130.

Moni, M. H. (2006b, December 2-3). Reducing the trade deficit between Japan and South Asia. An earlier version of this section was presented at the $5^{\text {th }}$ international conference of the Japan Economic Policy Association (JEPA), held at the College of Economics, Aoyama Gakuin University, Tokyo, Japan.

Nandy, A. (1995). The savage Freud and other essays on possible and retrievable selves. New Delhi \& London: Oxford University Press.

Nye, J. S. (Ed.). (1968). International regionalism: Readings. Boston, MA: Little Brown \& Company.

Ohji, T. (1992). Minami-Ajia wo shiru jiten [The dictionary of knowing South Asia]. Tokyo: Heibonsha.

Ohmae, K. (1995). The end of the nation state: The rise of regional economies. New York: Free Press.

Prueher, J. W. (1997, May 22). The US Pacific Command: Continuity of commitment to the AsiaPacific region. Remarks delivered by Commander-in-Chief, US Pacific Command, at the National Defense Studies Institute of Thailand, Bangkok).

Rozman, G. (2004). Northeast Asia's stunted regionalism: Bilateral distrust in the shadow of globalization. Cambridge: Cambridge University Press. 
SAARC free trade pact comes into force. (2006, January 2). Asian Economic News, p. A3.

Sareen, T. R. (2004). Subhas Chandra Bose, Japan and British imperialism. European Journal of East Asian Studies, 3(1), 69-97.

Small business checks in at hotel for companies (2004, November 28). Daily Yomiuri, p. A4.

Terry, E. (2002). How Asia got rich: Japan, China, and the Asian miracle. Armonk, NY: M.E. Sharpe.

Tho, T. V., Yutaka, H., \& Kwan, C. H. (2001). Saishin Ajia keizai to Nihon: Sinseiki no kyoryoku bijon [New cooperation vision for the new century of Asia and Japan]. Tokyo: Nihon Hyoronsha.
Thompson, G. (Ed.). (1998). Economic dynamism in the Asia-Pacific: The growth of integration and competitiveness. London: Routledge.

Vanaik, A. (2004). Globalization and South Asia: Multidimensional perspectives. New Delhi: Manohar Publications.

World Bank [WB]. (2005). World development indicators 2005. Washington, D.C.: World Bank.

Yamazaki, T., \& Takahashi, M. (Eds.). (1993). Nihon to Indo: Koryu no rekishi [Japan and India: History of cooperation]. Tokyo: Sanseido. 